\title{
Escape of Firedamp in Urban Development Areas in Ostrava - Karviná Coal District, Czech Republic
}

\author{
Vlastimil Hudeček*, Václav Zubíček, Pavel Zapletal
}

VŠB - Technical University of Ostrava, Faculty of Mining and Geology, Intitue of Mining Engineering and Safety, 17. listopadu 15, Ostrava - Poruba, 70833, Czech Republic

Corresponding Author Email: vlastimil.hudecek@vsb.cz

\section{https://doi.org/10.18280/eesrj.060406}

Received: 2 January 2019

Accepted: 10 June 2019

\section{Keywords:}

firedamp, abandoned mines with escaping firedamp, protection of undermined areas, active prevention, passive prevention

\begin{abstract}
The risk of uncontrolled escape of firedamp is one of the major manifestations of closing coal mines in the Ostrava - Karviná District in the Czech Republic. Mining activity was also carried out in areas close to urban or suburban development in the city of Ostrava, including its historical district.

The article presents aspects of dealing with the hazards as well as measures that have been implemented with respect to the risk of uncontrolled escape of firedamp. It outlines some of the applied approaches and equipment, which can eliminate this hazard. The figures included in the article document the current state of the solution.
\end{abstract}

\section{INTRODUCTION}

The Ostrava - Karviná District is the most important coalmining region in the Czech Republic, and i tis located in its eastern part. Figure 1 shows the coal deposits (lignite deposits are hatched, anthracite deposits are black).

Uncontrollable leakage of mine gases from old mine workings and mines being phased out, decommissioned and closed to the surface may occur in protected deposit areas and in mining claims of gassy mines being phased out, decommissioned and already closed.

This phenomenon is dangerous especially in the built-up areas at contact between the building and the subgrade and in the case of sewage systems and public supply systems, where explosive and/or suffocating gases can accumulate in the building, and after initiation, their explosion can occur or oxygen can be displaced from the air and the stifling atmosphere can be produced.

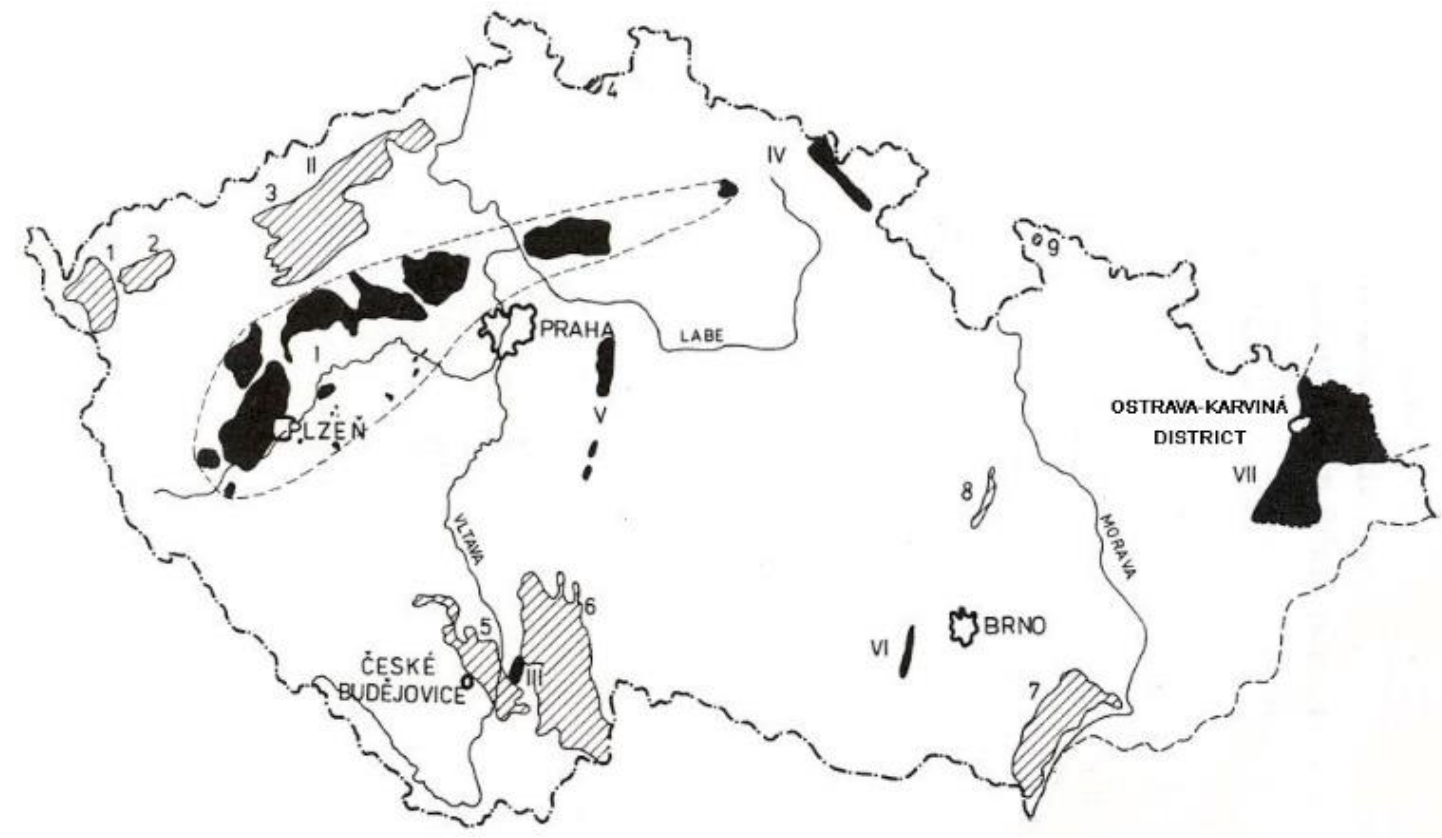

Figure 1. The location of the Ostrava - Karviná District in the Czech Republic

The main explosive component of mine gases is methane, the explosibility of which in mixture with the air moves in a range of $5-15 \%$. Owing to oxygen shortage, methane contained in mine gases emitted from closed mines does not usually form any explosive mixture. Nevertheless, it can become explosive after mixing with the air when penetrating 
to the enclosed spaces of buildings.

So that the explosion of a mixture of gases can take place, the concentration of methane in the mixture has to correspond to the explosive range; furthermore, initiation has to occur, i.e. energy for triggering the chemical reaction - explosion has to be supplied [1].This initiation in connection with buildings may be induced especially by electrical equipment, open fire and mechanical sparkle, and also by other causes. Another risk following from the leakage of mine gases into buildings is the formation of an atmosphere with decreased oxygen level due to oxygen displacement with the leaking gases [2].

The existence of the hazard arising from the uncontrollable leakage of mine gases to the surface has also been found abroad and confirmed by many incidents in the areas of mining claims of mines being phased out, decommissioned and closed and old mine workings in the Ostrava-Karviná Coalfield (Upper Silesian Basin).

\section{FINISHED MINING ACTIVITIES}

After finishing the mining activities in a good number of mines in the Ostrava region, the estimated volume of underground voids is about $30.106 \mathrm{~m}^{3}$; it is a case of voids of underground accumulation of methane. Gas emission rates in the given voids are different. From the voids, methane migrates to the surface in the main along two communication pathways. Those will then appear as point sources (e.g. exits of some mine workings) and planar sources, i.e. parts of coalbearing Carboniferous formation with the absence of impermeable overburden. As far as this problem is concerned, a list of mine workings with one end open to the surface in the Ostrava partial basin is provided. Here, 316 vertical mine workings and 62 adits are recorded. According to the Act No. 44/1988 Coll. (Mining Act), the adits and 245 vertical mine workings are old mine workings. If there is a safety hazard, the solution falls within the competence of the Ministry of the Environment. As for the remaining 71 vertical mine workings, the company OKD is obliged to treat them in the framework of the phase-out programme. All these mine workings were assessed as point sources of the hazard of methane leakage and divided into 2 categories - without hazard and with the hazard of gas leakage. The majority of 71 mine workings (compulsorily treated by the OKD) are mostly assessed as possible communication pathways for mine gases to the surface [3].

The leakage of methane from old mine workings represents a high risk factor that has so far resulted in accidents explosion and fatal injury (Salma buildings), serious injury due to an explosion in a house (Ostrava-Hrušov), deterioration of land with subsequent necessity of stopping construction activities, risk of explosions in already erected buildings, etc. With regard to the fact that methane leakage occurs even in heavily populated urban agglomeration of Ostrava, the acute hazard still exists that will not diminish in time.

As another example of the hazard, several critical situations that happened at Orlová in the year 2002 can be given; methane originating from old mine workings accumulated in the sewage system below the square and in the cellars of the health centre and a series of explosions threatened.

For monitoring the concentration of methane, several ten of measuring points were established. They automatically monitor these concentrations and collect data in the monitoring centre of the state-owned company DIAMO [4].
In principle, two ways of protection, independent of each other, can be used at present.

\section{PASSIVE PROTECTION OF UNDERMINED AREAS}

Passive protection is partly possible thanks to the monitoring system and the rapid transmission of information on increased risk of methane leakage, mainly at a drop in atmospheric pressure. After the sound of an emergency alarm, various measures are prescribed in the emergency plan; what is meant is above all the increasing of attention, ventilation of critical points, disconnection of electric power supply, etc.

Passive prevention focuses on the following areas:

- the controlled drainage of mine gases from underground,

- searching out and securing and decommissioning of yet not secured old mine workings,

- innovation and extension of monitoring systems,

- central control and evaluation station (dispatch centre) with a digitally processed database, connected to the Integrated Rescue System of the region.

\section{ACTIVE PROTECTION OF UNDERMINED AREAS}

Active protection is applied in the form of drainage (degasification) boreholes especially into the worked-out areas of former mining fields (gobs).

Active prevention is implemented by:

- the construction of active local gas drainage systems,

- new methods of phase-out and closure of still active mines in the Karviná partial part of the Ostrava-Karviná Coalfield in association with the use of possibilities of reducing uncontrollable area leakage of mine gases to the surface and simultaneously increasing the volumes of gases drained under control,

- designs of new types of active local drainage systems, including monitoring,

- $\quad$ design and possible construction and test operation of facilities for the use of mine gases containing a low and variable amount of methane.

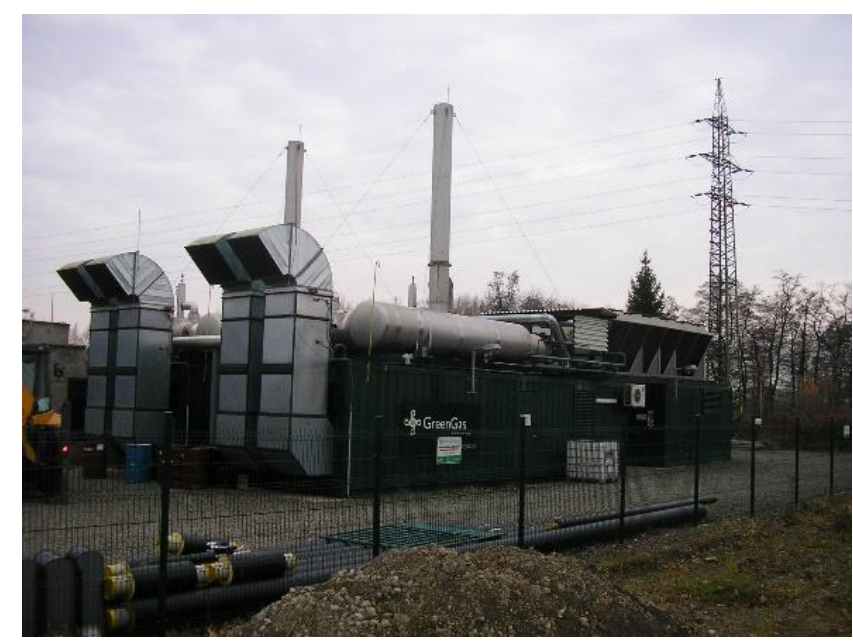

Figure 2. Cogeneration unit from the former František Mine

Hazardous situations, associated with the leakage of gases from underground, have occurred in many localities, where ventilation and gas drainage were gradually interrupted and mine workings were closed [5-8]. 
It can be expected that in the course of further phase-out of mining of coal deposits, the problems of organized gas drainage from abandoned mines will be really topical [9].

Figures 2 and 3 illustrate cogeneration units from the former František mine and the Muglinov site used in the undermined area.

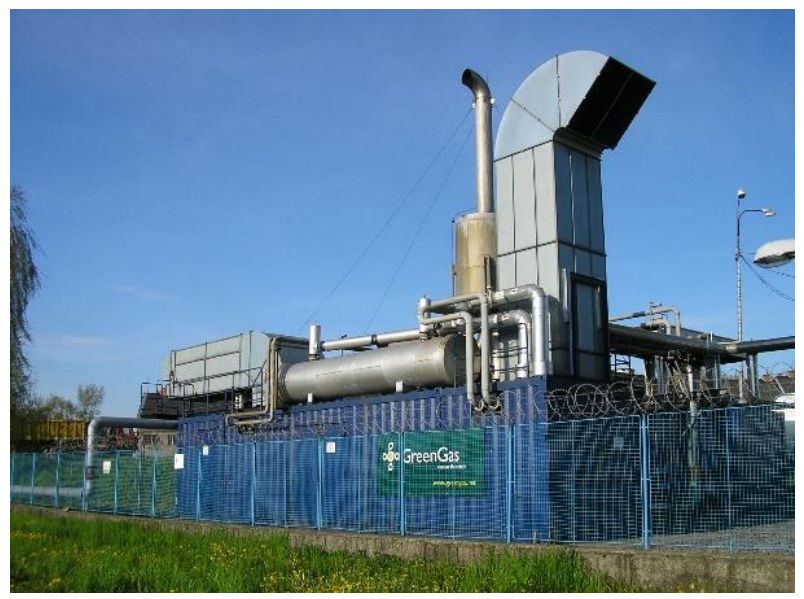

Figure 3. Cogeneration unit of location Muglinov

\section{CATEGORIZATION OF AREAS}

Areas affected by mining operations are divided according to the level of hazard of mine gas leakage as follows:

a) Areas with possible random uncontrollable leakage of methane to the surface

- are delimited by the zero isoline of effects of mining operations, so-called boundaries of subsidence troughs

b) Areas threatened by uncontrollable leakage of methane to the surface

- are delimited by the isoline of $50 \mathrm{~cm}$ thickness of overburden formations, occurring inside the area with possible random uncontrollable leakage of methane to the surface $[10$, 11]

c) Areas hazardous owing to uncontrollable leakage of methane to the surface

- are delimited by the outlines of areas of worked-out faces to a depth of $100 \mathrm{~m}$ below the surface increased by $50 \mathrm{~m}$ (safety zone). These areas are situated inside the areas threatened by uncontrollable methane leakage to the surface. The safety zones of main mine workings open to the surface are classified as areas hazardous owing to uncontrollable leakage of methane to the surface. The safety zones with a diameter of $25 \mathrm{~m}$ around 590 decommissioned shafts and adits occupy the total area of $1.16 \mathrm{~km}^{2}$.

d) Carboniferous outcrops

e) Areas in the surroundings of old mine workings and in the vicinity of decommissioned main mine workings and boreholes.

\section{PROTECTION OF BUILDINGS IN THE CASE OF FINISHED MINING ACTIVITIES}

\subsection{Protection of new buildings}

By the year 1998, building permits were issued for the area of Ostrava-Karviná Coalfield regardless of the leakage of mine gases to the surface.

Since the year 1998, the District Mining Authorities, when expressing their opinions on buildings in protected deposit areas, in the framework of permitting the buildings in the protected deposit areas according to the Mining Act, Article 19, have also expressed their opinions on the leakage of mine gases at the given point of the building. Specific ways of design-based protection of buildings are not, however, mentioned in the opinions of the District Mining Authorities because they are beyond the competence of the State Mining Administration.

In October 1998, experts in the field of construction and experts from the company DPB Paskov prepared a document on the permitting of buildings in the areas with the leakage of mine gases, dealing with the protection of both existing buildings and conditions of construction in the areas with possible leakage of mine gases to the surface. Building authorities were made familiar with this document. But based on legislation, these institutions cannot order builders to satisfy necessary measures to protect the buildings against mine gases. In spite of that, the implementation of protective measures against the penetration of methane into the building is already routinely required by many building authorities. Nevertheless, nobody checks whether or not this is done in the whole area of the Ostrava-Karvina Coalfield [3].

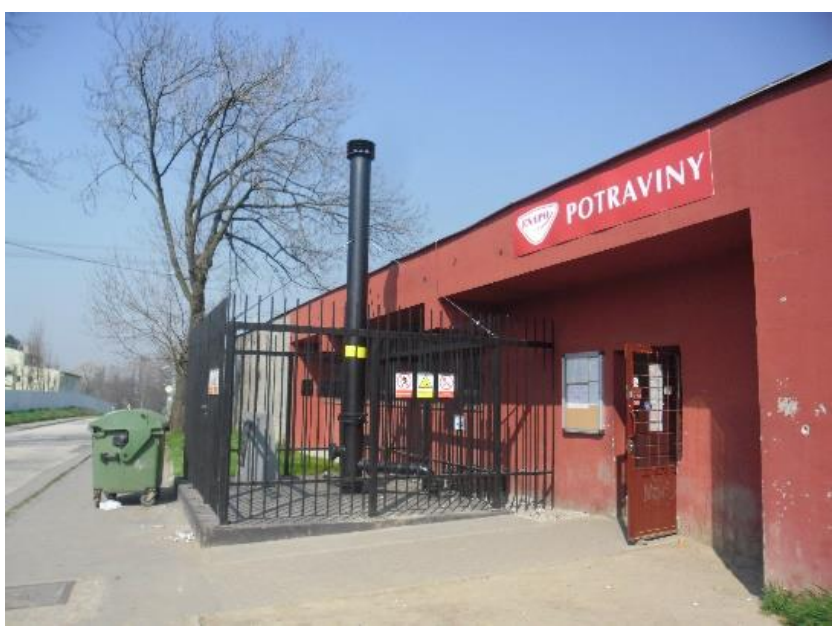

Figure 4. Building of shopping centre protected by means of gas drainage borehole $\mathrm{Na}$ Liščině street, Ostrava- Hrušov

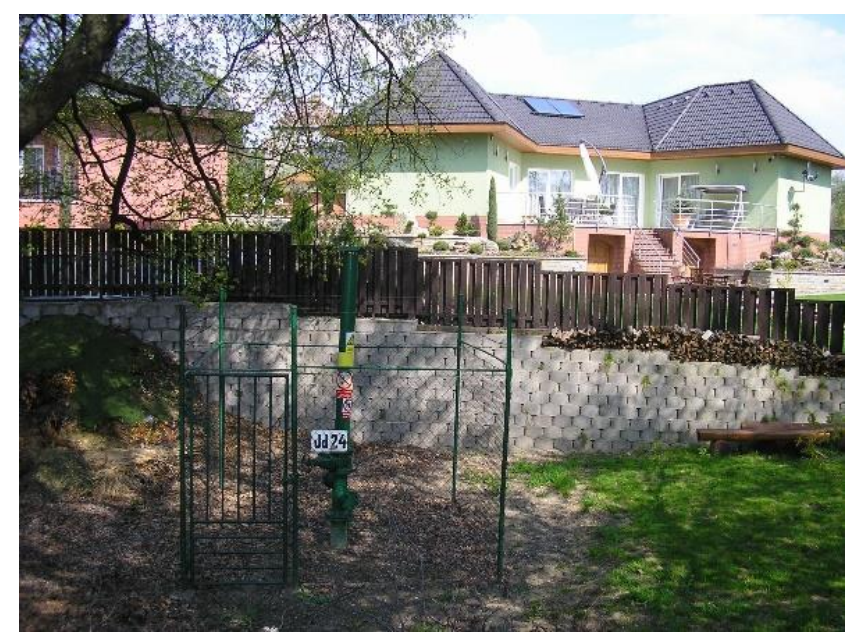

Figure 5. Protection of a family houses at Ostrava -Muglinov in the area of decommissioned prospect 


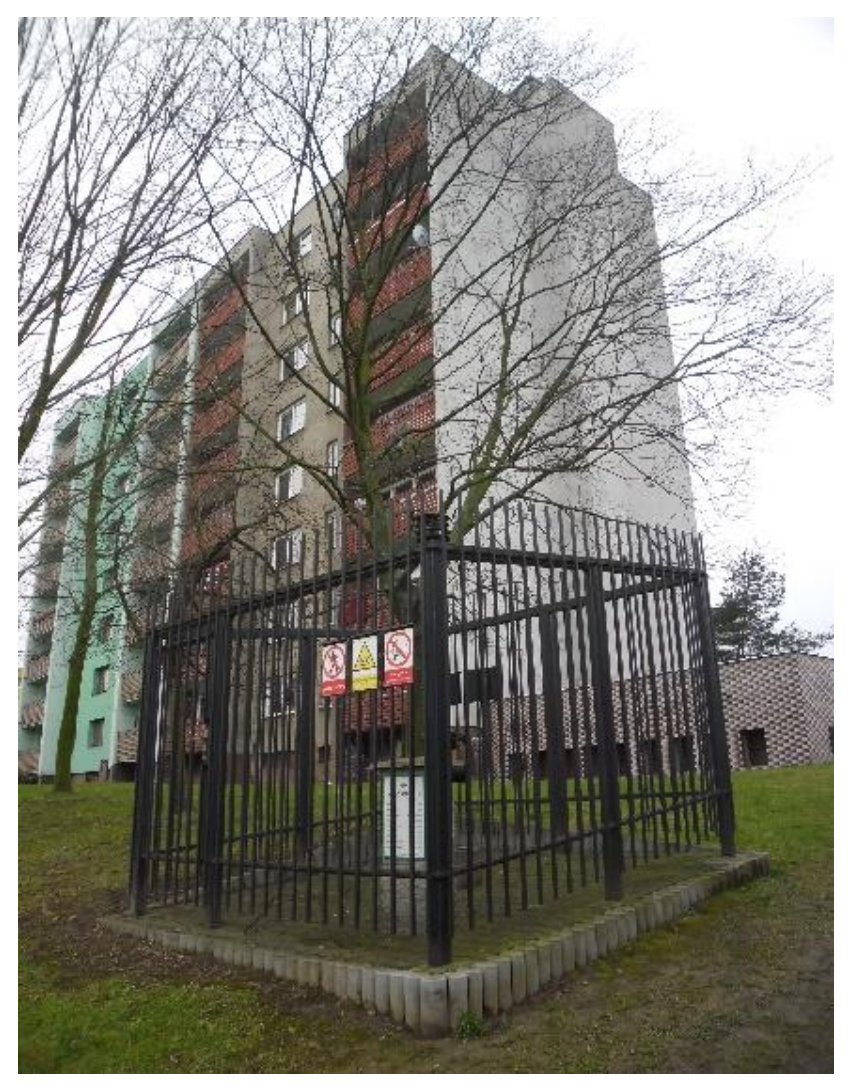

Figure 6. Protection of a panel house at Ostrava - Muglinov by means of gas drainage borehole

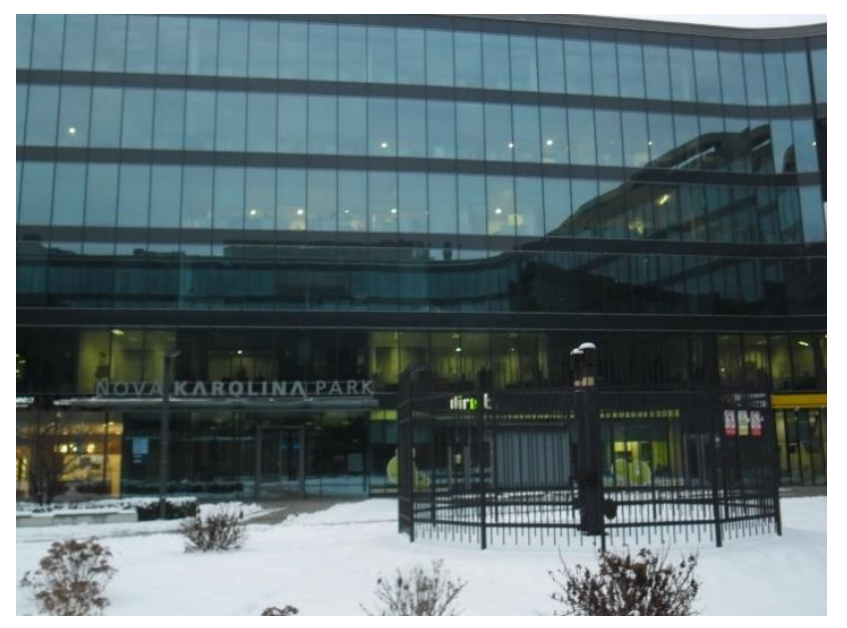

Figure 7. Protection of Nova Karolina Park at Ostrava by means of gas drainage borehole

Protection of Existing Buildings (Existing Buildings in Safety Pillars of Shafts and Adits).

The Decree No. 52/1997 Coll., in Article 11, Section 2 determines that for shafts filled with nonconsolidated backfill materials, the use of an area in the safety zone is acceptable only if other safety and protective measures were determined. During the decommissioning of the shafts in the framework of the phase-out programme, restoration of old mine workings and abandoned mine workings, the buildings were treated in some of the following ways:

- Removal of the building, in case of ineffective preventive measures (in the case of all decommissioned shafts with the exception of listed buildings).

- Alterations, especially construction of natural ventilation or installation of forced ventilation (as example of extensive alterations, listed buildings above decommissioned shafts can be given).

- Gas drainage boreholes, oriented towards below the building or its surroundings (Figures 4-7), drainage ditches around the buildings.

- Methanometers installed in buildings situated in safety zones.

\subsection{Degree of threat to buildings}

According to the threat of leakage of mine gases, buildings are divided into the following categories:

- degree 1 - safe building - measured methane concentrations do not exceed $0.1 \%$ at any point in the interior.

- degree 2 - threatened building - measured concentrations of methane in the interior are higher than $0.1 \%$, but they do not exceed $0.5 \%$.

- degree 3 - building is hazardous - measured methane concentrations in the interior are higher than $0.5 \%$ [12]

Existing Buildings Affected by Area Leakage of Mine Gases

The protection of existing buildings against the area leakage of mine gases from cavities caused by seam extraction was implemented primarily in the case of seams located at shallow depths below the surface. In Figures 4-7 there are examples of protection of buildings by means of gas drainage boreholes.

\section{CONCLUSIONS}

In the Ostrava-Karviná area, many municipalities and also towns are situated in undermined areas. A mine gas leaking to the surface could mean an immediate threat. For this reason, passive measures in the form of designation of places of gas leak and establishment of protection zones and exhaustion of gas at check points with subsequent combustion of the gas at the point of compressor discharge were implemented even in the past.

Although these measures contributed to securing safety in the surroundings, they did not use the energy potential of the mine gas and, on the contrary, they exhibited energy consumption (compressor drives) and loaded the air with emissions arising from open combustion of the mine gas.

In recent years, there was a significant shift from the point of view of securing safety in the surroundings, use of energy of the mine gas and environmental protection in the form of construction of cogeneration units combusting the mine gas at the points of its occurrence [12]. In addition to the abovementioned benefits in the area of safety, the economic effect of sales of generated power and heat is not negligible either.

The contribution was prepared with financial support from the project PL.3.22/2.3.00/12.03351.

\section{REFERENCES}

[1] Act No. 44/1988 Coll., (Mining Act) and Decree of Czech Mining Authority No. 52/1997 Coll., as amended.

[2] Project of Czech Mining Authority in Prague No.17/2002. (2002). Dynamics of Leakage of Mine Gases from Underground Voids of Closed Mines. Ostrava, VŠB TU -Ostrava, HGF.

[3] Solař, J. (2004). Protection of Buildings against Methane Leaking from the Ground. Informační centrum ČKAIT Praha. 
[4] Urban, P., Chovanec, J. (2004). Measurement of Methane in Undermined Areas. Ostrava, HGF, TUOstrava.

[5] Taraba, B., Pavelek, Z., Slovák, V., Janek, J. (2009). Effect of Pre-Treatment of the Coal on its Oxidation Behaviour, Mine Ventilation, Volume 2). Ninth International Mine Ventilation Congress, India, Oxford \& IBH Publishing Co. Pvt.Ltd. New Delhi ISBN 978-81204-1750-2.

[6] Taraba, B., Pavelek, Z. (2014). Investigation of the spontaneous combustion susceptibility of coal using the pulse flow calorimetric method: 25 years of experience. Fuel, 25: 101-105.

[7] Magnusková, J., Matušková, S., Bartoňová, J., Pavelek, Z. (2011). Problems of cooling sealed fire fields in underground coal mines. Journal of Mines, Metals \& Fuels, 59(10): 321-327.

[8] Xia, B.W., Zhao, B.Q., Lu, Y.Y., Liu, C.W., Song, C.P. (2016). Drainage radius after high pressure water jet slotting based on methane flow field. International Journal of Heat and Technology, 34(3): 507-512. https://doi.org/10.18280/ijht.340323

[9] Urban, P. (2005). Pomiar odgazowania w odwirtach kopalnianych. Systemy Wspomagania w Zarzadzaniu Środowiskiem. Polytechnika Slezská Gliwice.

[10] Richter, P., Pecharová, E. (2013). Short communication effects of mining activities on river water quality. Polish Journal of Environmental Studies, 22(4): 1269-1276.

[11] Gruca-Rokosz, R., Tomaszek, J.A., Koszelnik, P., Czerwieniec, E. (2011). Methane and carbon dioxide fluxes at the sediment-water interface in reservoirs. Polish Journal of Environmental Studies, 20(1): 81-86.

[12] Hudeček, V., Urban, P., Černá, K. (2011). New degassing trends in the underground parts of gases coal mines in the Czech Republic. 11th International Multidisciplinary Scientific GeoConference Location. Albena, Bulgaria, 20-25. 